\title{
REVIEW
}

Franklin T. Harkins, ed.

\section{Transforming Relations: Essays on Jews and Christians Throughout History in Honor of Michael A. Signer}

\author{
(Notre Dame: University of Notre Dame Press, 2010), xxv + 476 pp. \\ Katja Vehlow, University of South Carolina
}

Transforming Relations is a collection of twenty essays celebrating the work of Michael A. Signer, a Reform rabbi and the Abrams Professor of Jewish Thought and Culture at the University of Notre Dame from 1992 until his death in 2009. A number of contributors (e.g., Arnold Band) lovingly reflect on Signer as a student, colleague, teacher, and friend. The volume embraces the wide scope of Signer's research interests and presents current studies of Jewish and Christian encounters with the scriptural text and with one another in antiquity, the middle ages, and today. The book reflects Signer's key convictions that, firstly, a shared Biblical text and its exegesis are central points of convergence and divergence for Jews and Christians, and, secondly, that genuine inter-religious dialogue is only possible when the participating partners recognize each other as heirs of and participants in living and equal faith traditions.

Transforming Relations opens with a poem remembering Signer by Cyril O'Regan, a foreword by John van Engen, and an introduction by Franklin T. Harkins. It is divided into two parts. In Part One ("Ancient and Medieval Perspectives: Exegesis, Polemic, and Cultural Exchange"), David Novak discusses the concept of the law as a major divider between Jews and Christians and suggests that rabbinic Jews and Paul of Tarsus shared a basic understanding of the precovenantal (i.e., pre-Sinai and pre-Calvary) nature of the law while differing on its ultimate telos. Novak argues that a reconsideration of the rabbis and Paul might lead Jews and Christians to a deeper appreciation of themselves and each other. Israel J. Yuval's essay advocates "parallelomania," i.e., a quest for parallels and influences that expresses a lively and conflicted dialogue between the two religions in the first millennium. Employing John Scott's concept of "hidden transcripts," Yuval argues that rabbinic Judaism created a body of literature that, while seemingly sealed off from the outside world, engaged Christianity by refusing even to admit the opponent's existence.

The following four essays focus on the Victorines, a group of theologians based at the Augustinian Abbey of Saint-Victor in Paris and a topic of much interest to Signer. Grover A. Zinn investigates the spiritual and theological practice of the study and recitation of the Psalms at the abbey. Dale M. Coulter reconstructs the theoretical framework for Hugh of St. Victor's methodology for interpretation and exposes the literal approach that had characterized the enterprise of the Victorines and their Jewish counterparts. Boyd Taylor Coolman and Franklin T. Harkins analyze the exegetical practices of Richard of St. Victor and Andrew of St. Victor, two of Hugh's students. Rashbam's reflections on Song of Songs and Lamentations form the focus of Sara Japhet's chapter. E. Ann Matter elaborates on some of the many meanings given to the "Wandering Jew" motif in medieval Christian literature, while Lesley Smith examines the authorship of Hugh of St. Cher's Postilla in totam bibliam (Commentary on the Whole Bible) and suggests that scholars should pay closer attention to the Mendicant vocation of medieval Christian thinkers. Arjo 
Vanderjagt discusses the use of Hebrew by the fifteenth-century Dutch Christian Hebraist Wessel Gansfort in the context of an increasing scholarly awareness of the role of Christian antiSemitism in the past and present. Jeremy Cohen concludes this section with an article looking at the function of exegesis in a sixteenth-century Jewish anti-Christian polemic, the Shevet Yehudah (Staff of Judah).

In his brief introductory essay to Part Two ("Modern Perspectives: Theology, Praxis, and Perceptions of the Other"), Peter von der Osten-Sacken discusses the limits on inter-religious understanding and stresses in particular the need to acknowledge religious difference. Angela Kim Harkins echoes Signer's concerns. Christian theologians, she insists, should carefully study Jewish concepts, and she points to the problematic use of the term "people of god" in documents issued by the Second Vatican Council as an example of a less than careful use of theological terms. David Ellenson shows how Rabbi Hayim David Halevi, a former Chief Rabbi of Tel AvivJaffa, established a new halakhic basis for respectful relations with Christians based on ethical human obligations that transcended the traditional view of Christianity as idolatry.

The ensuing essays by Peter Ochs and John T. Pawlikowski engage Signer's theological philosophy directly. Ochs defends Signer's views on the importance of plain-sense medieval commentary for modern faith communities. Pawlikowski issues a series of challenges to Signer and to modern exegetes. He calls on Signer to take seriously both the problematic chapters in classical Christian exegesis and the impact of contemporary exegesis on inter-religious relations, especially as it pertains to the Jewish character of Jesus. Christian theologians should take the Hebrew Bible seriously as the Scriptures known to Jesus and should openly acknowledge that proselytization of Jews is not the goal of this discourse. Lastly, he argues that Signer paid insufficient attention to the ramifications of the Shoah for contemporary Jewish-Christian relations. David Fox Sandmel reflects on the implications of the (predominantly evangelical) Christian appropriation of Jewish ritual items and rituals, especially the Passover Seder. The phenomenon reflects recent scholarship on the Jewishness of Jesus, though it is perceived very differently by Jews and Christians. While Christians often view a Seder as a way to connect to the original Jesus, Jews tend to view appropriation as a form of Christian supersessionism. Hanspeter Heinz, recounting how his friendship with Signer transformed his own understanding of the Christian relationship with Judaism, concludes this volume with a study of the recent re-instatement of the Tridentine Rite, in particular the re-introduction of the Good Friday Intercession "For the Conversion of the Jews."

The diverse essays collected in this volume reflect Signer's wide-ranging interests and his impact on other thinkers. Scholars will cherish the rich articles to be found in Part One, but those who are engaged in Jewish-Christian relations on the community level will feel particularly drawn to Part Two. At the beginning of the twenty-first century, when many Christians are turning to Jewish practices in order to enrich their spiritual lives, and when Orthodox rabbinic authorities are quietly revising traditional stands vis-à-vis Christianity, this volume's call for intellectual and religious honesty could not be more timely. 